University of Nebraska - Lincoln

DigitalCommons@University of Nebraska - Lincoln

Papers in the Earth and Atmospheric Sciences

Earth and Atmospheric Sciences, Department

2008

\title{
Holocene Multidecadal- to Millennial-Scale Hydrologic Variability on the South American Altiplano
}

\author{
Erick Ekdahl \\ University of Nebraska-Lincoln \\ Sherilyn C. Fritz \\ University of Nebraska-Lincoln, sfritz2@unl.edu \\ Paul A. Baker \\ Duke University, pbaker@duke.edu \\ Catherine Rigsby \\ East Carolina University, Greenville, NC \\ Kirstin Coley \\ Royal Holloway College
}

Follow this and additional works at: https://digitalcommons.unl.edu/geosciencefacpub

Part of the Earth Sciences Commons

Ekdahl, Erick; Fritz, Sherilyn C.; Baker, Paul A.; Rigsby, Catherine; and Coley, Kirstin, "Holocene Multidecadal- to Millennial-Scale Hydrologic Variability on the South American Altiplano" (2008). Papers in the Earth and Atmospheric Sciences. 74.

https://digitalcommons.unl.edu/geosciencefacpub/74

This Article is brought to you for free and open access by the Earth and Atmospheric Sciences, Department of at DigitalCommons@University of Nebraska - Lincoln. It has been accepted for inclusion in Papers in the Earth and Atmospheric Sciences by an authorized administrator of DigitalCommons@University of Nebraska - Lincoln. 


\title{
Holocene multidecadal- to millennial-scale hydrologic variability on the South American Altiplano
}

\author{
Erik J. Ekdahl, ${ }^{1}$ Sherilyn C. Fritz, ${ }^{1,2}$ Paul A. Baker, ${ }^{3}$ Catherine A. Rigsby, ${ }^{4}$ and Kirstin Coley ${ }^{5}$
}

1 Department of Geosciences, The University of Nebraska-Lincoln, Lincoln NE 68588-0340, USA 2 Department of Geosciences and School of Biological Sciences, The University of Nebraska-Lincoln, Lincoln NE 68588, USA 3 Division of Earth and Ocean Sciences and Nicholas School of the Environment, Duke University, Durham NC 27708, USA 4 Department of Geology, East Carolina University, Greenville NC 27858, USA 5 Department of Geography, Royal Holloway College, Egham TW20 0EX, UK

Corresponding author - E. J. Ekdahl, present address: State Water Resource Control Board, 1001 I Street, Sacramento CA 95814, USA; email eekdahl@waterboards.ca.gov

\begin{abstract}
Precipitation on the South American Altiplano varies at a range of temporal scales. A long-term secular increase in moisture availability from the early/mid Holocene to the present, driven by increasing summer insolation resulting from precessional changes in the Earth's orbit, has been documented in earlier studies. However, higher frequency Holocene variability is not yet understood. Here we present high-resolution diatom assemblage data from two small Altiplano lakes, Lago Lagunillas and Lago Umayo, indicating changes in effective moisture in the southern tropical Andes at decadal, centennial and millennial timescales throughout the mid to late Holocene. A strong millennial-scale component, similar in pacing to periods of increased ice-rafted debris flux in the North Atlantic, is observed in both lake records, which suggests that regional precipitation and North Atlantic climate variability are coupled at these scales. The interpretation of the higher frequency variability is hampered by the small number of high-resolution continental and marine records for comparison.
\end{abstract}

Keywords: Altiplano, South America, Peru, Lake Titicaca, diatoms, tropical paleoclimate, hydrological variability, millennial scale, Holocene

\section{Introduction}

Climate fluctuates at a range of timescales from orbital to seasonal, responding to a variety of climate drivers, including fluctuations in solar output (Clemens, 2005) and ocean-atmosphere interactions (Stuiver et al., 1995; Hurrell, 1996; Bond et al., 1999). In tropical South America, records of climate variability are sparse, especially in the Southern Hemisphere tropics, and thus the spatial patterns of climate change and the role of various climate forcings at different temporal scales are still unclear. Existing continental records from tropical South America show variations in moisture availability at orbital scales, at least partially related to changing insolation associated with the preces- sional cycle (e.g., Martin et al., 1997; Seltzer et al., 2000; Haug et al., 2001; Wang et al., 2004). On the South American Altiplano, periods of high summertime insolation during the last 30,000 years (such as the last glacial maximum and present) were relatively wet, while $\sim 30,000$ cal. yr BP and the early to mid Holocene (when insolation was low) were drier (Baker et al., 2001a, b; Fritz et al., 2004).

Higher-frequency variability is also evident in paleoclimatic records from the Altiplano and elsewhere in the tropical Andes (Thompson et al., 2006). For example, Abbott et al. (1997) showed that the level of Lake Titicaca fluctuated by tens of meters at centennial timescales during the last 3,500 yr. In the northern tropical Andes, Polissar et al. (2006) correlated sedimentary records 
of catchment erosion spanning the last $1500 \mathrm{yr}$ with solar variation. But overall the spatial density of high-resolution records is low, thus it is unclear whether the observed patterns of lateHolocene high-frequency variability are regionally coherent and whether or not these modes of variation extended to the early to mid Holocene when insolation forcing was different.

During the instrumental period, ocean-atmosphere interactions in both the Pacific (Vuille et al., 2000; Garreaud et al., 2003) and Atlantic (Hastenrath et al., 2004) are known to impact climate in the tropical Andes. Thus, ENSO variability and associated fluctuations in tropical Pacific SSTs force inter-annual climate variation in the tropical Andes in both contemporary and paleoclimatic records (Rodbell et al., 1999; Vuille et al., 2000; Moy et al., 2002; Bradley et al., 2003). Baker et al. (2005) suggested that centennial- to millennial-scale variations in Holocene lake level at Lake Titicaca are positively correlated with records of ice-rafted debris in the North Atlantic (Bond et al., 2001). This apparent correlation between changes in the hydrologic cycle of tropical South America and climate variation in the high latitudes of the North Atlantic region may result from variations in the latitudinal gradients of tropical Atlantic SST (Baker et al., 2001a) associated with shifts in the mean position of the Atlantic Intertropical Convergence Zone (ITCZ) (Nobre and Shukla, 1996; Peterson et al., 2000; Chiang, 2002; Vellinga and Wood, 2002). The common patterns of variation in the two regions also may be linked to responses to a common large-scale forcing, such as solar intensity.

Additional high-resolution paleoclimate records from the tropical Andes are needed to clarify patterns of paleoclimatic variability in order to better evaluate the roles of Atlantic and Pacific SSTs and other potential sources of regional climate forcing (e.g., solar variability). Here we present diatom abundance data from two lakes on the South American Altiplano that, in combination with previously published climate reconstructions from Lake Titicaca, are used to define patterns of hydrologic variation at multidecadal to millennial timescales throughout the Lake Titicaca drainage basin. These records address the geographic extent and temporal pacing of Holocene hydrologic variability on the Altiplano and are used to examine whether centennial- to millennial-scale climate variability evident in late-Holocene Altiplano climate reconstructions (Abbot et al., 1997) is characteristic of the early and mid Holocene. We address some potential causes of the observed fluctuations in effective moisture by examining frequencies of variation and their relationship with potential climate drivers.

\section{Climate setting}

The Altiplano of South America is a broad high-elevation plateau (average elevation $\sim 3000 \mathrm{~m}$ above sea level [m a.s.1.]) located in the central Andes between about $10^{\circ}$ and $20^{\circ} \mathrm{S}$. The plateau is bordered on the east and west by high-elevation (locally 6,000+ $\mathrm{m}$ a.s.l.) mountains. Modern Altiplano precipitation is distinctly seasonal, with $\sim 85 \%$ of precipitation occurring during the austral summer (DJF) (Garreaud, 2000). Most of the moisture is ultimately derived from the tropical Atlantic and is transported to the Amazon basin by tropical easterlies, where it is recycled in intense summer convection within the Amazon basin (Vimeaux et al., 2006) before being uplifted onto the Altiplano. This transport pathway is part of a continental-scale climate system referred to as the South American Summer Monsoon (SASM; Zhou and Lau, 1998). Austral summer moisture convergence in the Amazon is determined by the strength of continental heating and by variation in moisture transport onto the continent by the trade winds. On the Altiplano at $\sim 15^{\circ}$ S, wet-season precipitation tends to occur as distinct events lasting from several days to over a week. Atmospheric conditions during precipitation events are characterized by strong easterly upper-atmosphere flow, whereas dry periods within the wet season are characterized by an increased westerly component (Garreaud 1999, 2000).

On inter-annual timescales, increased upper-level westerlies and increased subsidence over the Altiplano and central Amazon tend to cause drier conditions to prevail during El Niñnos, whereas La Niña years tend to be wetter (Aceituno, 1988; Lenters and Cook, 1997; Zhou and Lau, 2001). However, the strength of this correlation is weak, and both wet and dry years can respectively occur during El Niño and La Niña events (Vuille et al., 2000).

\section{Study sites and methods}

Lago Lagunillas and Lago Umayo are located west of Lake Titicaca on the high-elevation Altiplano (Figure 1). Lago Umayo $\left(15.44^{\circ} \mathrm{S}, 70.10^{\circ} \mathrm{W}, \sim 3,880 \mathrm{~m}\right.$ a.s.1.) is located approximately 17 $\mathrm{km}$ from the western edge of Puno Bay, Lake Titicaca. The deep basin $(>30 \mathrm{~m})$ is at the centre of the lake, with a broad shallow flat shelf at the margin that is heavily populated with aquatic macrophytes. Lago Lagunillas $\left(15.44^{\circ} \mathrm{S}, 70.44^{\circ} \mathrm{W}, \sim 4,220 \mathrm{~m}\right.$ a.s.1.) is located approximately $60 \mathrm{~km}$ west of Lago Umayo. Modern Lagos Umayo and Lagunillas have dammed outlets and active outflow, but both may have been closed-basin lakes at times in the past. Lago Umayo is slightly more alkaline and saline than Lago Lagunillas.

Overlapping sediment cores were taken in 2001 using a Russian peat corer. The cores were sampled continuously at $1 \mathrm{~cm}$ resolution for diatoms, pollen and stable isotopes. Here, we report on the diatom record from both lakes; the pollen and isotopic results will be the subject of future papers.

Sediments for diatom analysis were prepared for the entire length of each core sequence following standard methodology (Battarbee, 1986). A weighed aliquot of sediment was chemically digested with cold $\mathrm{HCl}$ and hydrogen peroxide to remove, respectively, carbonate and organic material. Microspheres were added to the residual material to estimate diatom abundance (valves per gram sediment weight). Cleaned material was settled onto cover slips, dried and mounted using Zrax, a high refractive-index diatom mounting material (RI > 1.70). At least 300 valves were counted per slide.

Core chronologies were constructed using respectively 10 and 12 accelerator mass spectrometry ${ }^{14} \mathrm{C}$ dates from Lago Umayo and Lago Lagunillas (Table 1; Figure 2). ${ }^{14} \mathrm{C}$ dates were calibrated using CALIB 5.0.2 (Stuiver et al., 2005) using the Holocene Southern Hemisphere calibration set of McCormac et al. (2004). The age-depth relationship for each lake was constructed by fitting a fifth-order (for Umayo) and a fourth-order (for Lagunillas) polynomial through the calibrated ages. Two samples from Lago Lagunillas were measured in duplicate; in these cases, the average $14 \mathrm{C}$ age was used in the calibration and age-model construction. In Lago Umayo, the sediment-water interface was collected at a core depth of $\sim 57-59 \mathrm{~cm}$. In Lago Lagunillas, loose unconsolidated material near the sediment-water interface was not captured. Consequently, the youngest sediments in Lago Lagunillas (which begin at a core depth of approximately $78 \mathrm{~cm}$ ) were ${ }^{14} \mathrm{C}$ dated to $\sim 1,800 \mathrm{cal}$. yr BP. The apparent age-reversal observed in the upper $10 \mathrm{~cm}$ of core recovered from Lago Lagunillas is likely due to disturbance within the upper sediment as a result of coring. The average age of the three ${ }^{14} \mathrm{C}$ dates in the upper $10 \mathrm{~cm}$ of sediment provides a good estimate of the age of the uppermost core sediment.

To estimate the temporal pacing of inferred lake-level oscillations observed in the diatom assemblages, we performed multitaper method spectral analysis (Mann and Lees, 1996) on specific diatom taxa from both Lago Umayo and Lago Lagunillas. Prior to spectral analysis, records were re-sampled to create uni- 


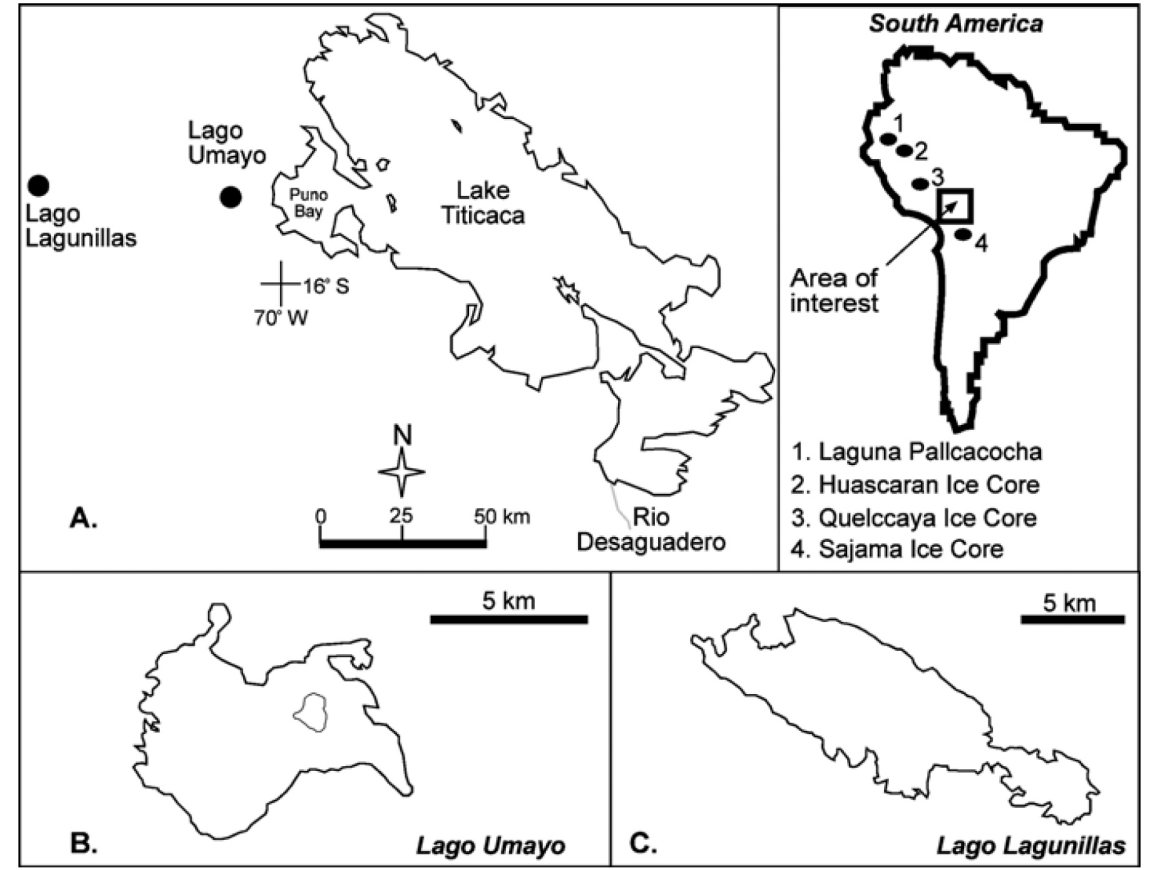

Figure 1. (A) Location of Lake Titicaca and study sites, Peru-Bolivia. (B) Lago Umayo, Peru. (C) Lago Lagunillas, Peru.

Table 1. Radiocarbon ages of total organic matter from Lago Umayo and Lago Lagunillas

\begin{tabular}{|c|c|c|c|c|c|c|}
\hline Lake & Depth (cm) & $\begin{array}{c}\text { Age } \\
\left({ }^{14} \mathrm{C} \text { yr BP }\right)\end{array}$ & $\begin{array}{l}\text { Error } \\
\pm\end{array}$ & $\begin{array}{l}\text { Laboratory } \\
\text { number }\end{array}$ & $\delta^{13} \mathrm{C}$ & $\begin{array}{c}\text { Cal. yr BP } \\
\text { (median probability) }\end{array}$ \\
\hline Umayo & 57-59 & $>$ Mod & & OS-43257 & -18.1 & 0 \\
\hline Umayo & 204-206 & 3470 & 30 & OS-43259 & -25.3 & 3665 \\
\hline Umayo & $249-251.5$ & 3700 & 30 & OS-43260 & -24.6 & 3961 \\
\hline Umayo & $351-353$ & 4170 & 25 & OS-43261 & -26 & 4641 \\
\hline Umayo & $545.5-548$ & 5260 & 35 & OS-43262 & -22.6 & 5962 \\
\hline Umayo & $634-636.5$ & 5600 & 45 & OS-43263 & -20.9 & 6344 \\
\hline Umayo & $676.5-679.5$ & 5640 & 35 & OS-43264 & -23.6 & 6362 \\
\hline Lagunillas & $75-78$ & 1970 & 35 & OS-43054 & -18.08 & 1860 \\
\hline Lagunillas & $76-78$ & 1860 & 25 & OS-43256 & -9.06 & 1743 \\
\hline Lagunillas & $399.5-402.5$ & 4930 & 45 & OS-43056 & -13.2 & 5616 \\
\hline Lagunillas & $406.5-409.5$ & 5080 & 40 & OS-43057 & -12.32 & 5780 \\
\hline Lagunillas & $491.5 \mathrm{a}$ & 5350 & 30 & OS-52699 & -14.67 & 6080 \\
\hline Lagunillas & $491.5 b$ & 5470 & 35 & OS-52277 & -14.47 & 6230 \\
\hline Lagunillas & $589-592$ & 5740 & 30 & OS-43254 & -13.1 & 6465 \\
\hline Lagunillas & 594-597.5 & 5980 & 30 & OS-43253 & -13.8 & 6745 \\
\hline Lagunillas & $638-640$ & 7010 & 40 & OS-43255 & -16.5 & 7784 \\
\hline Lagunillas & $738 a$ & 7240 & 40 & OS-52700 & -18.42 & 7997 \\
\hline Lagunillas & $738 b$ & 7260 & 40 & OS-52278 & -18.41 & 8014 \\
\hline
\end{tabular}

Calibrated ages calculated from Stuiver et al. (2005) and McCormac et al. (2004).

formly spaced time series and normalized to unit variance using the program Analyseries (Paillard et al., 1996). The resampled time series have a uniform spacing of 19.98 years in Lago Lagunillas and a uniform spacing of 9.99 years in Lago Umayo, allowing for resolution of periodic signals with periods of $\sim 40$ and $\sim 20$ years, respectively.

\section{Results}

Lago Umayo

The long-term trend in the diatom flora of Lago Umayo is characterized by a general decrease of benthic and saline dia- 

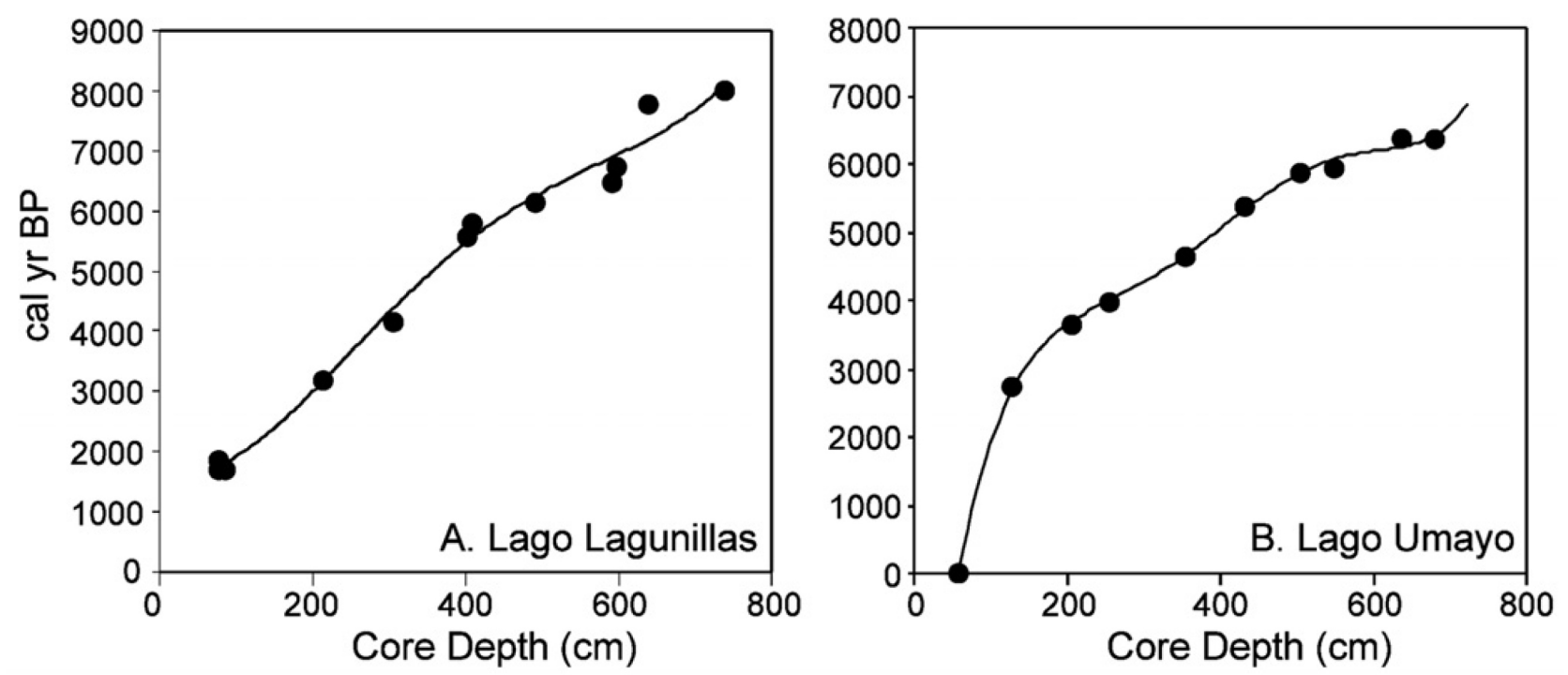

Figure 2. Age-depth relationships for Lago Lagunillas (A) and Lago Umayo (B). Calibrated dates are median probability ages.

tom abundance from the mid Holocene to the present (Figure 3). The oldest sediments $(6,500-5,500$ cal. yr BP) were dominated by Denticula keutzingii, Gomphonema pumilum, and smaller proportions of cymbelloid and Cocconeis species. Denticula keutzingii is common in Altiplano lakes and appears to reflect increased salinity and/or benthic habitat. Gomphonema, cymbelloid, and Cocconeis are cosmopolitan diatoms found in waters with widely varying chemistries; however, these diatoms are obligate benthic species that grow on aquatic macrophytes and other substrates. Higher abundance of benthic species implies lowered lake level (increased benthic diatom habitat area), as a result of reduced precipitation.

A major change in the diatom assemblage occurred at approximately 5,500 cal. yr BP, with the first appearance of Cyclotella stelligeroides, a planktic, mesoeutrophic species that grows in the nearshore areas of Lake Titicaca (Tapia et al., 2003) and in smaller moderately shallow freshwater lakes on the Altiplano. The appearance of $C$. stelligeroides was accompanied by a rapid decrease in the abundance of saline diatoms, indicating that Lago Umayo waters became significantly more dilute at this time. This freshening trend continued with the appearance at 3,800 cal. yr BP of Cyclostephanos andinus, a large oligosaline centric diatom. The abundance of $C$. andinus fluctuated but generally increased throughout the remainder of the record (3,800 cal. yr BP-present), reaching a maximum in the youngest sediment sample).

The stratigraphy of Lago Umayo is dominated by discontinuously laminated carbonates and massive silty and organicrich carbonates prior to $\sim 4,000$ cal. yr BP. After $\sim 4,000$ cal. yr BP, sediment from the lake is almost uniformly dark green silts and clays with only a trace carbonate component. This stratigraphy conforms to a trend of increasing moisture availability that began in the mid Holocene and has continued to the present. The abundance of carbonates prior to $\sim 4,000 \mathrm{cal}$. yr BP is interpreted as resulting from increased local aridity and evaporative enrichment of Lago Umayo waters, resulting in increased carbonate deposition. Higher lake levels, and more dilute waters, during the last 4,000 years have made conditions within the lake unfavorable for carbonate deposition.

In addition to the general freshening trend throughout the length of the record, the diatom abundances vary at decadal to millennial timescales (Figure 3). Decadal-scale fluctuations are most prominent in the oldest part of the record, where sampling frequency was approximately six years. Sample spacing increases in younger sediments, which prohibits resolution of decadal-scale fluctuations. Where resolved, decadal-scale fluctuations are superimposed upon centennial-scale variations, which are observed throughout the entire record. An example of centennial-scale variability is evident in the C. stelligeroides record between 5,500 and 4,500 cal. yr BP. These pulses likely reflect fluctuations in lake level driven by regional precipitation changes. Variability at similar frequencies is observed in the record of each individual diatom taxon. Millennial-scale variability is muted but is best observed in the abundance of saline diatoms. Fluctuations in saline diatom abundance are forced by regional precipitation change.

\section{Lago Lagunillas}

The Lago Lagunillas diatom record also indicates low lake level and saline conditions during the early to mid Holocene, followed by a gradual increase in lake level. Near-modern lake levels and salinities appear to have been established at approximately 4,500 cal. yr BP (Figure 4). Pseudostaurosira zeilleri, a small benthic diatom indicative of elevated salinity or high conductivity, dominated the flora in the oldest sediments. Denticula keutzingii also was abundant in this portion of the record. Saline diatoms decreased from $>80 \%$ of the record at $8,200 \mathrm{cal}$. yr BP to $\sim 0 \%$ at 4,500 cal. yr BP. From 4,500 cal. yr BP to the present, the abundance of saline diatoms was generally less than $10 \%$. Centric diatoms first appear in Lago Lagunillas at 5,700 cal. yr BP as a sudden peak in $C$. stelligeroides, followed by the appearance of C. andinus about $3,800 \mathrm{cal}$. yr BP. The timing of this freshening is similar to the initial freshening pulse observed in Lago Umayo (at $~ 5,500$ cal. yr BP). Lake level fluctuated from 4,500 yr BP to the present, but lake levels were above the outlet, so salinity never rose to significant levels.

The timings of sedimentological changes in Lago Lagunillas are similar to those observed in Lago Umayo. Organic-rich silts dominate from approximately $\sim 5,500 \mathrm{cal}$. yr BP to the present, with the exception of three periods, from 4,700 to 4,200 cal. yr $\mathrm{BP}, 3,000$ to 3,200 cal. yr BP and 2,000 to 1,450 cal. yr BP, when sediments became carbonate rich. Prior to $\sim 5,500 \mathrm{cal}$. yr BP, sediment was comprised of carbonate and carbonate-rich diatomite. As in Lago Umayo, the abundance of carbonate-rich sediments is interpreted as reflecting lower precipitation input and increased evaporation, which led to evaporative enrichment of 


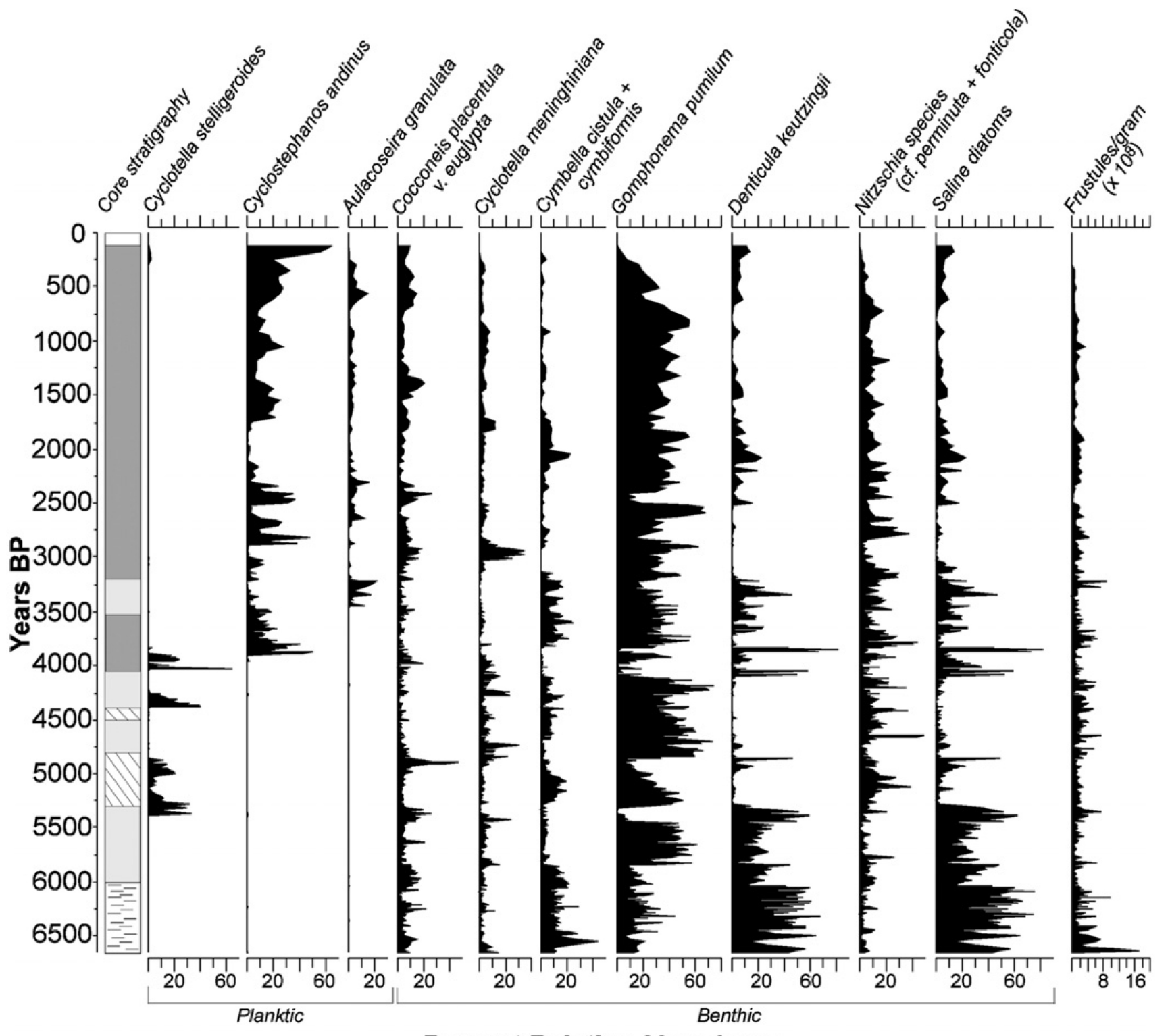

\section{Percent Relative Abundance}

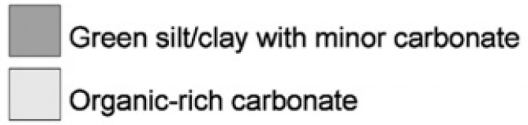

\section{Silty carbonate \\ Carbonate with organic laminae}

Figure 3. Relative diatom abundance from Lago Umayo, Peru. The curve for saline diatoms sums the abundance of major salinity-tolerant taxa, including Anomoensis sphaerophora, Cymbella pusilla, Navicula veneta, Craticula pampeana, Craticula halophila, Nitzschia dissipata v. media, Pseudostaurosira zeilleri, Staurosira construens fo. subsalina, Denticula elegans, and Denticula keutzingii. A general stratigraphic column is included, illustrating downcore changes in sedimentology.

Lago Lagunillas waters and increased carbonate precipitation and/or preservation.

In addition to decadal- to centennial-scale fluctuations, distinct millennial-scale oscillations are apparent in several of the diatom taxa. These fluctuations are most prominent in the records of C. placentula, G. pumilum, Nitzschia perminuta + fonticola, Pseudostaurosira construens v. venter and C. andinus. Millennialscale fluctuations in benthic diatoms relative to planktic species represent major fluctuations in lake level and salinity and hence moisture availability. The millennial-scale fluctuations persist throughout the duration of the record.

\section{Pacing of wet-dry fluctuations on the Altiplano}

Time-series analysis of diatom relative abundance in each of the lakes shows statistically significant (>99\% confidence interval) millennial, centennial, and multidecadal-band peaks in both lakes (Figure 5). While periodicities are given for individual spectral peaks in Figure 5, the millennial-scale signal is often a wide band encompassing a considerable frequency range. The presence of shared spectral peaks in both lake records suggests that a regional forcing was responsible for observed variations in diatom assemblages. 


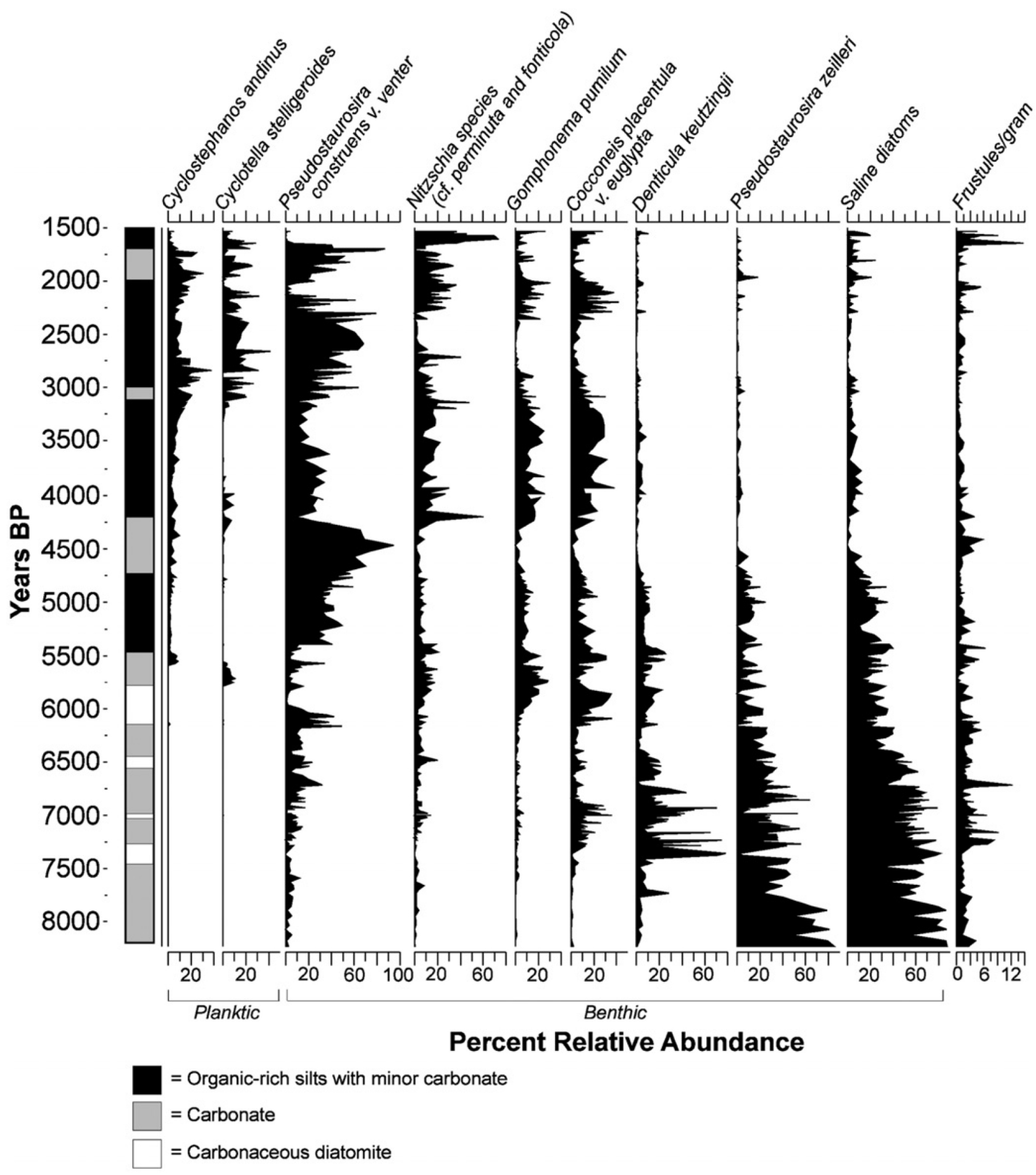

Figure 4. Relative diatom abundance from Lago Lagunillas, Peru. The curve for saline diatoms sums the abundance of major salinity-tolerant taxa, including Anomoensis sphaerophora, Cymbella pusilla, Navicula veneta, Craticula pampeana, Craticula halophila, Nitzschia dissipata v. media, Pseudostaurosira zeilleri, Staurosira construens fo. subsalina, and Denticula keutzingii. A general stratigraphic column is also included, illustrating down-core changes in sedimentology.

\section{Discussion}

Understanding the patterns of past precipitation variability in the tropical Andes at multidecadal to millennial scales, and the forcing mechanisms that govern this variation, is a key element in understanding the phasing and integration of global climate signals. Variability of precipitation on the Altiplano, whether of natural or anthropogenic origin, is of vital importance for modern agriculturalists, pastoralists and city dwellers that face increasing threats from global climate change (Bradley et al., 2006). The similarity in the pattern and phasing of hydrologic changes in Lago Lagunillas and Lago Umayo indicates that these records reflect large spatial-scale climate fluctuations. Thus, changes in diatom assemblages, interpreted as changing lake level or salin- 

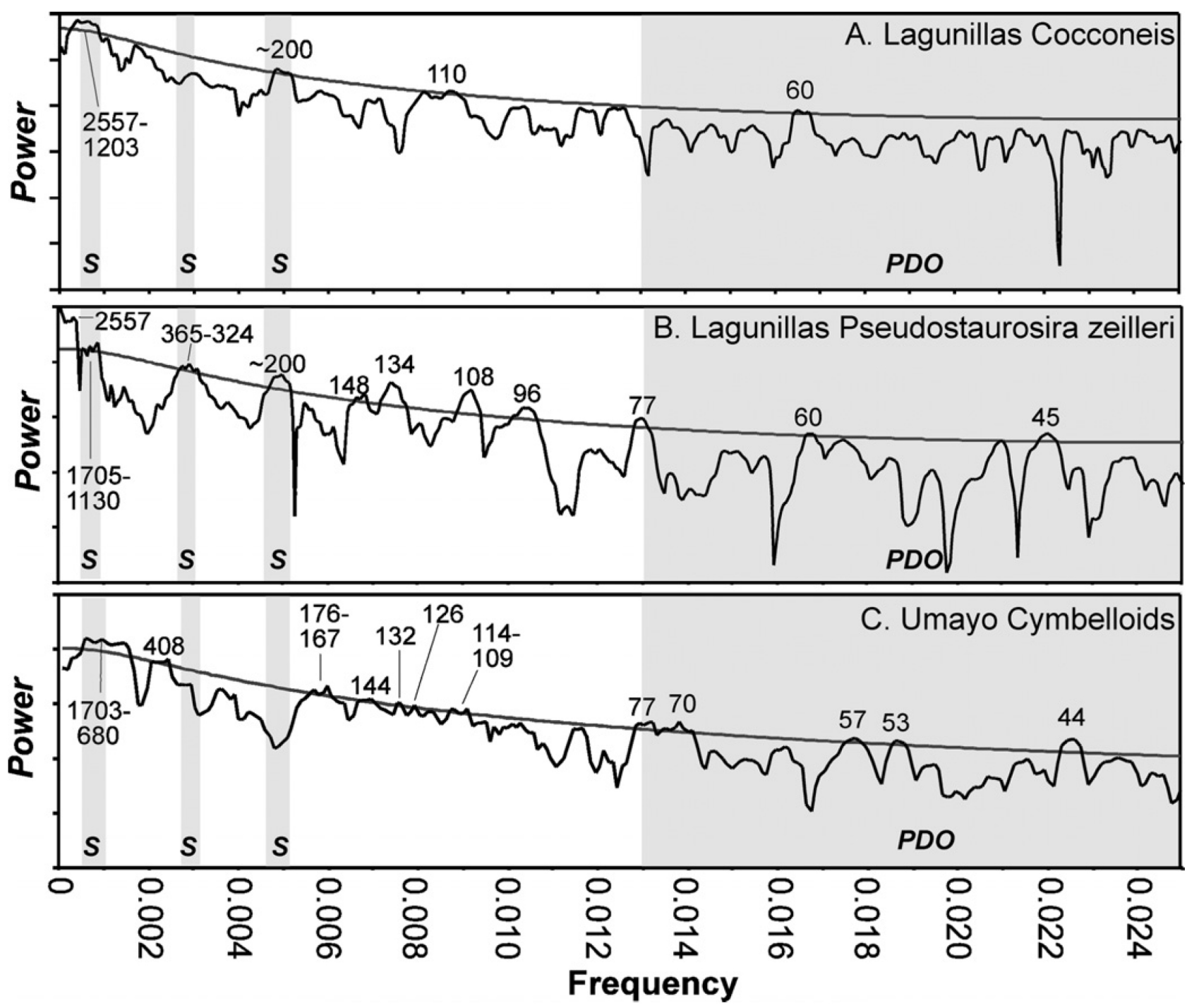

Figure 5. Multitaper method (MTM) spectral analysis power spectra from selected diatom assemblages in Lago Lagunillas (A and B) and Lago Umayo (C). Peaks that plot above the $99 \%$ confidence interval (grey line) are labeled by periodicity. Grey shaded regions marked by an $\mathrm{S}$ indicate periodicities of observed solar variability (Clemens, 2005). Shaded region marked by PDO indicates range of observed variability for the Pacific Decadal Oscillation (Minobe, 1997).

ity, occur nearly simultaneously in both lakes (Figure 6A) despite somewhat different limnological characteristics and morphometry, and hence different sensitivities and response times. Both records display a sharp increase in lake level at $\sim 5,500 \mathrm{cal}$. yr BP and a steady freshening thereafter, as saline diatoms decrease to background levels by about 4,000 cal. yr BP. Superimposed upon this trend is common variability at multidecadal to millennial scales. The pacing and direction of this variation at centennial to millennial scales is similar to the lake-level fluctuations observed in Lake Titicaca (Figure 6C), particularly from 8,000 to 4,000 cal. yr BP. This similar pacing corroborates the notion that all these records are broadly representative of climate variation in the northern Altiplano. The correlation between the Lago Lagunillas and Umayo records at high frequencies also supports the overall robustness of our age models.

There is some evidence that solar variation may have played a role in forcing precipitation variability on the Altiplano, based on the correspondence of Umayo and Lagunillas spectral peaks (Figure 5) with periods previously inferred for solar variability. Specifically, the $200-210 \mathrm{yr}$ peak in the diatom flora from
Lago Lagunillas is similar to the de Vries solar cycle, observed in several records in the Pacific Basin (Evans et al., 2001; Hu et al., 2003) and in other records of solar variability (Wagner et al., 2001). However, the statistical significance of this peak is weak in Lago Umayo. The 350 yr peak in Lago Lagunillas is similar to observed changes in the rate of ${ }^{10} \mathrm{Be}$ production and variations in tree ring width (Clemens, 2005), although its significance is slightly lower than the $99 \%$ threshold in Lago Umayo. Thus, if solar variability is important in forcing Holocene climate, its role in this region seems to be of secondary importance.

An increase in ENSO frequency (to modern levels) in the mid to late Holocene has been inferred from the sediment record of the Andean Laguna Pallacacocha, Ecuador (Rodbell et al., 1999; Moy et al., 2002). The resolution of our study does not allow us to resolve variation in the ENSO band; however, there is no obvious correspondence between the fluctuations in Lago Umayo and Lagunillas and variation in the Ecuadoran record smoothed to the same temporal resolution (Figure 6B). In fact, it is not clear what changes in precipitation would be expected on the Altiplano given an increase in ENSO frequency or amplitude. For 

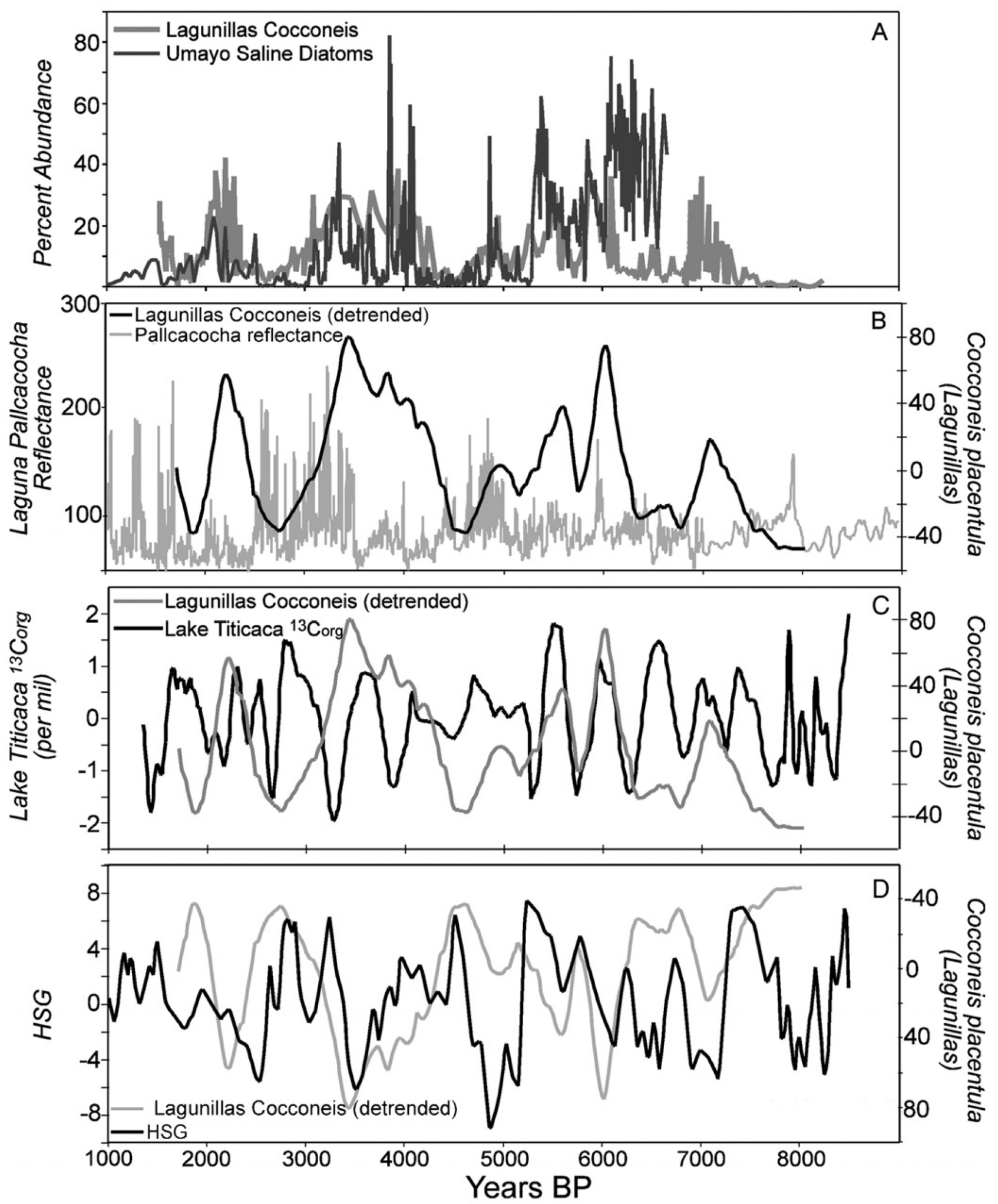

Figure 6. (A) Saline diatoms from Lago Umayo and Cocconeis placentula from Lago Lagunillas. (B) Comparison of the 10-point running average reflectance data from Laguna Pallcacocha (Moy et al., 2002) and the detrended record of Cocconeis placentula from Lago Lagunillas. (C) Cocconeis placentula (a benthic lake-level indicator) versus $\delta^{13} \mathrm{C}_{\text {org }}$ from Lake Titicaca, which is a proxy for lake level (Baker et al., 2005). In (C), both records have been detrended. (D) Hematite stained grain (HSG) record from the North Atlantic (Bond et al., 2001) compared with the filtered record of Cocconeis placentula from Lago Lagunillas. Note that the $y$-axis for the diatom record is reversed, so that periods of low benthic diatom abundance (high lake level and wet conditions on the Altiplano) correspond to cold and wet conditions in the North Atlantic. 
example, if an increased frequency of dry years (El Niño) is accompanied by increased frequency of wet years (La Niña), the long-term effect on Altiplano lake level is likely to be negligible.

Decadal variability in regions that are strongly influenced by the Pacific is commonly attributed to variations in the strength and sign of the Pacific Decadal Oscillation (PDO; Minobe, 1997; Mantua et al., 1997) or other decadal-scale variability in the Pacific Basin (e.g., Frauenfeld et al., 2005). The multidecadal variation at periodicities of 44-77 $\mathrm{yr}$ in both Lago Lagunillas and Lago Umayo is consistent with these observed modes of Pacific variability. While currently there are no climate records that demonstrate a strong PDO influence in the tropical Andes, the known Pacific influence on modern Altiplano precipitation (Vuille et al., 2000; Garreaud et al., 2003), suggests that there is a potential for PDO-scale Pacific ocean-atmosphere dynamics to influence hydrologic variability in the Lake Titicaca region. However, similar spectral peaks are evident in proxy and model reconstructions of North Atlantic SSTs (Delworth and Mann, 2000); thus, it is difficult to identify the forcing of multidecadal variability in the tropical Andes from spectral data alone.

Multidecadal- to millennial-scale changes in tropical Atlantic SSTs also may have played a role in producing the variation observed in our records. Both the Lago Lagunillas and Lago Umayo records show significant $(99 \%)$ variation at millennial frequencies $(1,000-1,700 \mathrm{yr})$ that are characteristic of North Atlantic variability (Bond et al., 2001). To evaluate how North Atlantic SST variation is related to precipitation on the Altiplano, we compared the North Atlantic HSG record (Bond et al., 2001) with a filtered record from Lago Lagunillas of the abundance of Cocconeis placentula (Figure 6D), a benthic diatom that reflects lake-level change. This comparison demonstrates a correspondence between wet conditions on the Altiplano (low Cocconeis), and cool conditions associated with the ice-rafted debris record from the North Atlantic, similar to the relationship observed for Lake Titicaca lake level (Baker et al., 2005). This correlation, which appears particularly robust from 8,000 to 4,000 cal. yr BP, argues for a significant role for Atlantic SST variability in driving millennial-scale precipitation fluctuations on the Altiplano.

In the instrumental record, tropical North Atlantic SST and Altiplano precipitation during the austral summer wet season are correlated: anomalous southward shifts of the ITCZ in the Atlantic, hence cold SST anomalies in the tropical North Atlantic, are associated with anomalously wet conditions on the Altiplano (Hastenrath et al., 2004). The characteristic period of the tropical Atlantic meridional SST gradient, driven mostly by SST variations in the tropical South Atlantic, is 12 to 13 years (Mehta, 1998). We believe that an analogous relationship exists on longer timescales, such as those described in the present study. Thus, persistent anomalies in the mean annual latitude of the western Atlantic ITCZ appear to correlate with the oxygen isotopic composition of ice in the Qualcaya ice cap (Peterson and Haug, 2006) and with our evidence for increased (or decreased) lake levels on the Altiplano.

\section{Conclusions}

Patterns of lake-level variation inferred from the diatom stratigraphy of Lagos Umayo and Lagunillas are similar to those observed previously from Lake Titicaca (Baker et al., 2001a, b, 2005), supporting the position that the inferred precipitation charges are coherent over large regions. Superimposed upon a secular increase in moisture beginning $~ 5,500 \mathrm{yr} B P$ is periodic variability at multidecadal to millennial scales, which is characteristic of both the mid and late Holocene and is coherent in both lakes at multiple temporal scales. In both sites, strong peri- odicity in the millennial band, similar to the pacing of the North Atlantic HSG record (1,000-1,700 yr), suggests a relationship between North Atlantic temperatures and precipitation variation on the Altiplano. Both lakes also show strong variation at multidecadal to centennial scales at frequencies that are characteristic of variation in Atlantic and Pacific SSTs, as well as solar activity. Thus, it is difficult to attribute these patterns of highfrequency change to a particular forcing. As a result, unraveling the relative importance of various drivers on tropical moisture budgets at decadal to centennial scales awaits the generation of additional high-resolution records and modeling studies that address the dynamic controls of tropical climate variation at appropriate spatial and temporal scales.

\section{Acknowledgments}

This work was supported by NSF grants to Baker (EAR), Rigsby (EAR) and Fritz (ATM) and by the Office of Research of the University of Nebraska. EJE generated the diatom stratigraphies, statistical analyses, and figures, and wrote the primary draft of the manuscript. SCF cowrote the manuscript and contributed in the conceptual development of the project and the interpretation of the data. PAB directed the fieldwork and contributed to discussions relating to the conceptual framework of the research, interpretation of the data, and to writing of the manuscript. CAR and KC assisted in the field and KC in the laboratory. Ashley Ballantyne assisted with fieldwork.

\section{References}

Abbott, M.B., Binford, M.W., and Kelts, K.R. 1997: A $3500{ }^{14} \mathrm{C}$ yr high-resolution record of lake level changes in Lake Titicaca, Bolivia/Peru. Quaternary Research 47, 169-80.

Aceituno, P. 1988: On the functioning of the Southern Oscillation in the South American sector. Part 1: surface climate. Monthly Weather Review 116, 505-24.

Alley, R.B. 2000: The Younger Dryas cold interval as viewed from central Greenland. Quaternary Science Reviews 19, 213-26.

Baker, P.A., Seltzer, G.O., Fritz, S.C., Dunbar, R.B., Grove, M.J., Tapia, P.M., Cross, S.L., Rowe, H.D., and Broda, J.P. 2001a: The history of South American tropical precipitation for the past 25,000 years. Science 291, 640-43.

Baker, P.A., Rigsby, C.A., Seltzer, G.O., Fritz, S.C., Lowenstein, T.K., Bacher, N.P., and Veliz, C. 2001b: Tropical climate changes at millennial and orbital timescales on the Bolivian Altiplano. Nature 409, 698-700.

Baker, P.A., Fritz, S.C., Garland, J., and Ekdahl, E.J. 2005: Holocene hydrologic variation at Lake Titicaca, Peru/Bolivia, and its relation to North Atlantic climate variation. Journal of Quaternary Science 20, 655-62.

Battarbee, R.W. 1986: Diatom analysis. In Berglund, B.E., editor, Handbook of Holocene palaeoecology and palaeohydrology. John Wiley, 527-70.

Bond, G., Kromer, B., Beer, J., Muscheler, R., Evans, M.N., Showers, W., Hoffmann, S., Lotti-Bond, R., Hajdas, I., and Bonani, G. 2001: Persistent solar influence on North Atlantic climate during the Holocene. Science 294, 2130-36.

Bond, G.C., Showers, W., Elliot, M., Lotti, R., Hajdas, I., Bonani, G. and Johnson, S. 1999: The North Atlantic's 1-2 kyr climate rhythm: relation to Heinrich Events, Dansgaard/Oeschger Cycles and the Little Ice Age. In Clark, P.U., Webb, R.S. and Keigwin, L.D., editors, Mechanisms of global climate change at millennial time scales. American Geophysical Union, 35-58.

Bradley, R.S., Vuille, M., Hardy, D.R., and Thompson, L.G. 2003: Low latitude ice cores record Pacific sea surface temperatures. Geophysical Research Letters 30, 1174-77.

Bradley, R.S., Vuille, M., Diaz, H., and Vergara, W. 2006: Threats to water supplies in the tropical Andes. Science 312, 1755-56. 
Chiang, J.C.H. 2002: Deconstructing Atlantic Intertropical Convergence Zone variability: influence of the local cross-equatorial sea surface temperature gradient and remote forcing from the eastern equatorial Pacific. Journal of Geophysical Research 107, 3-1-3-16.

Clemens, S.C. 2005: Millennial-band climate spectrum resolved and linked to centennial-scale solar cycles. Quaternary Science Reviews 24, 521-31.

Delworth, T.L. and Mann, M.E. 2000: Observed and simulated mul tidecadal variability in the Northern Hemisphere. Climate Dynamics 16, 661-76.

Evans, M.N., Cane, M.A., Schrag, D.P., Kaplan, A., Linsley, B.K., Villalba, R., and Wellington, G.M. 2001: Support for tropicallydriven Pacific decadal variability based on paleoproxy evidence. Geophysical Research Letters 28, 3689-92.

Frauenfeld, O.W., Davis, R.E., and Mann, M.E. 2005: A distinctly interdecadal signal of Pacific ocean-atmosphere interaction. Journal of Climate 18, 1709-18.

Fritz, S.C., Baker, P.A., Lowenstein, T.K., Seltzer, G.O., Rigsby, C.A., Dwyer, G.S., Tapia, P.M., Arnold, K.K., Ku, T., and Luo, S. 2004: Hydrologic variation during the last 170,000 years in the southern hemisphere tropics of South America. Quaternary Research 61, 95-104.

Garreaud, R.D. 1999: Multiscale analysis of the summertime precip itation over the central Andes. Monthly Weather Review 127, 901-21.

- 2000: Intraseasonal variability of moisture and rainfall over the South American Altiplano. Monthly Weather Review $128,3337-46$.

Garreaud, R., Vuille, M., and Clement, A.C. 2003: The climate of the Altiplano: observed current conditions and mechanisms of past changes. Palaeogeography, Palaeoclimatology, Palaeoecology 94, $5-22$.

Hastenrath, S., Polzin, D., and Francou, B. 2004: Circulation vari ablity reflected in ice core and lake records of the southern tropical Andes. Climatic Change 64, 361-75.

Haug, G.H., Hughen, K.A., Sigman, D.M., Peterson, L.C., and Rohl, U. 2001: Southward migration of the intertropical convergence zone through the Holocene. Science 293, 1304-308.

Hu, F.S., Kaufman, D., Yoneji, S., Nelson, D., Shemesh, A., Huang, Y., Tian, J., Bond, G., Clegg, B., and Brown, T. 2003: Cyclic variation and solar forcing of Holocene climate in the Alaskan subarctic. Science 301, 1890-93.

Hurrell, J.W. 1996: Influence of variations in extratropical winter time teleconnections on Northern Hemisphere temperature. Geophysical Research Letters 23, 665-68.

Lenters, J.D. and Cook, K.H. 1997: On the origin of the Bolivian high and related circulation features of the South American climate. Journal of the Atmospheric Sciences 54, 656-77.

Mann, M.E. and Lees, J.M. 1996: Robust estimation of background noise and signal detection in climatic time series. Climatic Change 33, 409-45.

Mantua, N.J., Hare, S.R., Zhang, Y., Wallace, J.M., and Francis, R.C. 1997: A Pacific interdecadal climate oscillation with impacts on salmon. Bulletin of the American Meteorological Society 78, 1069-79.

Martin, L., Bertaux, J., Correge, T., Ledru, M.-P., Mourguiart, P., Sifeddine, A., Soubies, F., Wirrmann, D., Suguio, K., and Turcq, B. 1997: Astronomical forcing of contrasting rainfall changes in tropical South America between 12,400 and 8800 cal yr B.P. Quaternary Research 47, 117-22.

McCormac, F.G., Hogg, A.G., Blackwell, P.G., Buck, C.E., Higham, T.F.G., and Reimer, P.J. 2004: SHCal04 Southern Hemisphere calibration 0-11.0 cal kyr BP. Radiocarbon 46, 1087-92.

Mehta, V.M. 1998: Variability of the tropical ocean surface tempera tures at decadal-multidecadal timescales. Part I: the Atlantic Ocean. Journal of Climate 11, 2351-75.
Minobe, S. 1997: A 50-70 year climatic oscillation over the North Pacific and North America. Geophysical Research Letters 24, 683-86.

Moy, C.M., Seltzer, G.O., Rodbell, D.T., and Anderson, D.M. 2002: Variability of El Nino/Southern Oscillation activity at millennial timescales during the Holocene epoch. Nature 420, 162-65.

Nobre, P. and Shukla, J. 1996: Variations of sea surface temperature, wind stress, and rainfall over the tropical Atlantic and South America. Journal of Climate 9, 2464-79.

Paillard, D., Labeyrie, L., and Yiou, P. 1996: Macintosh program performs time-series analysis. Eos, Transactions of the American Geophysical Union 77, 379.

Peterson, L.C. and Haug, G.L. 2006: Variability of the mean latitude of the Intertropical Convergence Zone as recorded by riverine input of sediments to the Cariaco Basin, Venezuela. Palaeogeography, Palaeoclimatology, Palaeoecology 234, 97-113.

Peterson, L.C., Haug, G.H., Hughen, K.A., and Rohl, U. 2000: Rapid changes in the hydrologic cycle of the tropical Atlantic during the last glacial. Science 290, 1947-51.

Pollisar, P.J., Abbott, M.B., Wolfe, A.P., Bezada, M., Rull, V., and Bradley, R.S. 2006: Solar modulation of Little Ice Age climate in the tropical Andes. Proceedings of the National Academy of Science 103, 8937-42.

Rodbell, D.T., Seltzer, G.O., Anderson, D.M., Abbott, M.B., Enfield, D.B., and Newman, J.H. 1999: An 15,000-year record of El Ninodriven alluviation in southwestern Ecuador. Science 283, 516-20.

Seltzer, G., Rodbell, D., and Burns, S. 2000: Isotopic evidence for late Quaternary climatic change in tropical South America. Geology $28,35-38$.

Stuiver, M., Grootes, P.M., and Braziunas, T.F. 1995: The GISP2 d18O climate record of the past 16,500 years and the role of the sun, ocean, and volcanoes. Quaternary Research 44, 341-54.

Stuiver, M., Reimer, P.J., and Reimer, R.W. 2005: Calib 5.0 http:// calib.qub.ac.uk/calib/manual/

Tapia, P.M., Fritz, S.C., Baker, P.A., Seltzer, G.O., and Dunbar, R.B. 2003: A late Quaternary diatom record of tropical climate history from Lake Titicaca (Peru and Bolivia). Palaeogeography, Palaeoclimatology, Palaeoecology 194, 139-64.

Thompson, L.G., Mosley-Thomspon, M., Brecher, H., Davis, M., Leon, B., Les, D., Lin, P., Mashiotta, T., and Mountain, K. 2006: Abrupt tropical climate change: past and present. Proceedings of the National Academy of Sciences 103, 10 536-43.

Vellinga, M. and Wood, R.A. 2002: Global climatic impacts of a col lapse of the Atlantic thermohaline circulation. Climatic Change $54,251-67$.

Vimeaux, F., Gallaire, R., Bony, S., Hoffman, G., and Chiang, J.C.H. 2006: What are the climate controls on $\delta D$ in precipitation in the Zongo Valley (Bolivia)? Implications for the Illimani ice core interpretation. Earth and Planetary Science Letters 240, 205-20.

Vuille, M., Bradley, R.S., and Keimig, F. 2000: Interannual climate variability in the central Andes and its relation to tropical Pacific and Atlantic forcing. Journal of Geophysical Research 105, 12 447-60.

Wagner, G., Beer, J., Masarik, J., Muscheler, R., Kubik, P.W., Mende, W., Laj, C., Raisbeck, G.M., and Yiou, F. 2001: Presence of the solar de Vries cycle ( 205 years) during the last ice age. Geophysical Research Letters 28, 303-306.

Wang, X.L., Auler, A.S., Edwards, R.L., Cheng, H., Cristalli, P.S., Smart, P.L., Richards, D.A., and Shen, C-C. 2004: Wet periods in northeastern Brazil over the past $210 \mathrm{kyr}$ linked to distant climate anomalies. Nature 432, 740-43.

Zhou, J. and Lau, K.M. 1998: Does a monsoon climate exist over South America? Journal of Climate 11, 1020-40.

. 2001: Principal modes of interannual and decadal variability of summer rainfall over South America. International Journal of Climatology 21, 1623-44. 